\title{
Challenges Faced by Freight Forwarders in their Operations in Chennai City, Tamil Nadu
}

\author{
S. Vasantha ${ }^{1}$ and S. Meena ${ }^{2}$ \\ ${ }^{1}$ Professor, ${ }^{2}$ Associate Professor, School of Management Studies, \\ Vels Institute of Science, Technology and Advanced Studies, Chennai, Tamil Nadu, India \\ E-Mail: Vasantha.sms@velsuniv.ac.in,meena.sms@velsuniv.ac.in
}

\begin{abstract}
Logistics is the movement of goods from one place to other.Freight forwarders play a major role in logistics operations.The main objective of the freight forwarders is to dispatch the shipments via carriers. Forwarder has the ability to arrange cargo movement from one destination to another within a short limit of time.It is tough for a company to ship goods at a normal price without a forwarder. Forwarders are having a long-term relationship with carriers and obtain good deals in the least possible time. The forwarding operations and company strategy differ from one company to another, by providing different value-added services. Customer satisfaction plays an important role in business. The present study aimed to find out the challenges faced by freight forwarders in their operations. Due to various factors, they face challenges and that could be the reason for their failures. In some cases, due to hindrance, they may not be able to satisfy the customer needs. The major challenges faced are due to government policies and regulation (GST), importers or exporters, port authorities, warehousing of the goods, red tapism of insurance companies, customs clearance, liner companies, infrastructure problems etc. The study involves both primary and secondary data. A well-structured Questionnaire prepared to elicit the data from the freight forwarders. Sample size identified is $\mathbf{5 0}$ forwarders. The study is concluded by giving the ways to ways to overcome the challenges faced by the Freight Forwarders.
\end{abstract}

Keywords: Challenges, Customer Satisfaction, Logistics

\section{INTRODUCTION}

Logistics is involved in all the facets of our daily lives. Logistics is the main backbone to a national and international supply chain. While being compared with developed countries, such as China, US etc, the Indian logistics industry is still considered to be underdeveloped. Freight forwarders act as the middle person between exporter and importer. Forwarders can also act as NVOCC (Non-Vessel Operating common carrier). The main difference between a normal Non-Vessel Operating Common Carriers and freight forwarder is the NVOCC will be having containers on their own. Forwarders can also act as Customs House Agents. The main components of the forwarding company are customers. Forwarders need the license to run the business. Freight forwarders have the expertise that allows them to prepare the documentation works for doing shipments, most of them are been processed in a paperless environment. The main task of the forwarding agent is the consolidation of consignments. Freight Forwarders do all procedural and documentation involved in the clearance on behalf of the exporters and importers. The forwarders use the latest technologies to solve the logistics challenges improvise the Forwarders strength and expertise in gaining customers. The Indian government had taken several initiatives to help the forwarders. Mainly the infrastructure has to be developed in India to meet up with the international standards. Service tax collected from freight forwarders is huge and none are happy with it. So they have to be very careful while handling the shipments.

\section{LITERATURE REVIEW}

Murphy et al., and Daley et al., (2001) said freight forwarders are known as trade specialists whooffer the variety of services in International trade. They also studied the factors in the selection of the international freight forwarders. Jean Francois Arivis et al., (2007) state that forwarding firm is the company that helps to connect different parts of the world. David (2013) mentioned that freight forwarders are different from customs brokers and they are also different from Non-Vessel Operating Common Carriers (NVOCCs). Saran (2014) stated about the number of major and minor ports India. He did research on how much volume the ports are handling and also did research on the average growth of container growth. Nishimura $e t$ al., (2009) state that the timely advent and exits of vessels play a difficulty in arriving and outbound cargo traffic. Park and Kim, (2005)observed that port delay happens due to extra custom requirements, for visual verification of contents. Mostly there could be long delays and in turn, cost increases with port activities. Notteboom, (2006) studied Out-dated technology and inefficient IT system and inadequate proper equipment in ports are the main issues for the delay in port operations in India.

Apples and Swielande, (1998) describes the role of the customs department. The main roles remain revenue collection, poorly trained officials that make the business challengingSreedevi (2008)said in the study that the shipments from India are lacking perfection in many sectors. The problems faced by ports are mainly due to overstuffing and labor. By overcoming these two main problems, the shipping trade will be in full fledge.Sanjai, (2006) found that the logistics industry is the interplay of technology, infrastructure, new types of services which help 
to reduce their logistics costs. Changing government policies on taxation and regulation of service plays an important role in forwarding.GirishGujar (2006) analyzed that role of multimodal transportation in India and also highlighted thechallenges and shortcomings. India is facing the problem because of legislation, policy failures, and infrastructure limitation.

\section{OBJECTIVES OF THE STUDY}

1. To identify the issues of freight forwarders with importers and exporters.

2. To analyse the challenges of freight forwarders in Container freight station operations and customs clearance.

\section{RESEARCH METHODOLOGY}

The study has been used both primary and secondary data.The data has been collected from the importers and exporters in Chennai city. The Convenience samplingtechnique has been used to choose the respondents. The sample size used for the study is 50 samples. The structured Questionnaireswas used to collect the primary data.The Secondary data was gathered from the records of freight forwarders association, Reports, Journal articles, Magazines, Books, Websites, Previous studies, and libraries. The collected data were tabulated and coded for analyzing in the SPSS software. The study is confined to importers and exporters in Chennai city

\section{A. Data Analysis and Interpretation}

TABLE I SHIPMENTS HANDLED PER DAY

\begin{tabular}{|c|c|c|}
\hline Shipments & No.of Respondents & Percentage \\
\hline $1-3$ & 11 & 22 \\
\hline $4-9$ & 26 & 52 \\
\hline $10-20$ & 13 & 26 \\
\hline Total & 50 & 100 \\
\hline \multicolumn{2}{|r|}{ (Source: Primary data) }
\end{tabular}

The above table shows the number of shipments handled daily by respondents per day. 52 percentage of the respondents handle 4-9 shipments per day. 26 percentage of respondents handle 10-20 shipments, 22 percentage handle 1-3 shipments daily.

TABLE II ISSUES WITH EXPORTERS AND IMPORTERS

\begin{tabular}{|l|c|c|}
\hline Issues with exporter and importer & Mean & Std. Deviation \\
\hline Nature of product (in different types) & 4.26 & .664 \\
\hline Over expectation (Promptness) & 3.30 & .909 \\
\hline Terms of contracts & 4.40 & .606 \\
\hline Lack of co- operation & 3.68 & .621 \\
\hline Lack of Export/ Import knowledge & 1.66 & .745 \\
\hline
\end{tabular}

(Source: Primary data)
Based on the mean score the Terms of contracts(4.40) is the main issue that is experienced by freight forwarder (respondents) and the next is problem with different product, product in invoice and product they sending is different (4.26), another one is because of over expectation (Promptness) (3.30), also due to lack of co-operation from exporter and importer side(3.68). But as per the analysis it shows that the exporter and importer having knowledge in exporting and importing (1.66) From this, it is can conclude that main problem faced by the freight forwarder from the side importer and exporter are due to terms of contract and product related issues.

TABle III Problems Regarding Container Freight Station (CFS)OPERATIONS

\begin{tabular}{|l|c|c|}
\hline Option & No of respondents & Percentage \\
\hline Yes & 31 & 62 \\
\hline No & 19 & 38 \\
\hline Total & 50 & 100 \\
\hline \multicolumn{2}{|c|}{ (Source: Primary data) }
\end{tabular}

It is inferred that 62 percentage of the respondents are facing problems regarding CFS operations and 38 percentage are not facing any problems.

TABLE Iv CHALlenges In CuSTOMS Clearance

\begin{tabular}{|l|c|c|}
\hline \multicolumn{1}{|c|}{$\begin{array}{c}\text { The efficiency of the Customs } \\
\text { clearance }\end{array}$} & Mean & $\begin{array}{c}\text { Std. } \\
\text { Deviation }\end{array}$ \\
\hline $\begin{array}{l}\text { Import shipments cleared and } \\
\text { delivered as per schedule }\end{array}$ & 4.12 & .689 \\
\hline $\begin{array}{l}\text { Export shipments cleared and shipped } \\
\text { as per schedule }\end{array}$ & 4.20 & .639 \\
\hline $\begin{array}{l}\text { Customs clearance a transparent } \\
\text { process }\end{array}$ & 2.98 & .795 \\
\hline $\begin{array}{l}\text { Receive adequate and timely } \\
\text { information when regulations change }\end{array}$ & 2.44 & .577 \\
\hline $\begin{array}{l}\text { Traders demonstrating high levels of } \\
\text { compliance receive expedited Customs } \\
\text { clearance }\end{array}$ & 2.42 & .785 \\
\hline \multicolumn{2}{|l|}{ Source: Primary data) }
\end{tabular}

Based on mean score respondents related to the efficiency of customs clearance, it is clear that the import shipments are cleared and delivered as scheduled (4.12), export shipments are cleared and shipped as scheduled(4.20).

TABLE V CORRELATION BETWEEN EXPORTER/IMPORTER AND PORT AUTHORITIES ISSUES

\begin{tabular}{|c|l|c|c|}
\hline \multicolumn{2}{|c|}{} & Exim & Port \\
\hline \multirow{4}{*}{ Export /import } & Pearson Correlation & 1 & $.507^{* *}$ \\
\cline { 2 - 4 } & Sig. (2-tailed) & & .000 \\
\cline { 2 - 4 } & $\mathrm{N}$ & 50 & 50 \\
\hline \multirow{4}{*}{ Port } & Pearson Correlation & $.507^{* *}$ & 1 \\
\cline { 2 - 4 } & Sig. (2-tailed) & .000 & \\
\cline { 2 - 4 } & $\mathrm{N}$ & 50 & 50 \\
\hline
\end{tabular}




\section{B. Correlation}

$\mathrm{H}_{0}$ : There is no relationship between export/import issues and port authority issues.

$\mathrm{H}_{1}$ : There is the relationship between export/import issues and port authority issues.

Correlation is significant at the 0.01 level (2-tailed).

$\mathrm{p}$ value is less than 0.01 , hence the null hypothesis rejected at $1 \%$ significance level.

The correlation relation between exporter /importer issues, port authority issues is 0.507 which indicates that $50.7 \%$ relationship between exporter/importer issues and port authorities at $1 \%$ significant level.

\section{DISCUSSION}

The problems faced by the freight forwarder from the side importer and exporter are due to terms of contract and product related issues. Lack of advanced equipment, the lacking of infrastructure could be the issues with Port authorities. The efficiency of customs clearance it could be observed from the analysis that from the study it is clear that Customs clearance is not a transparent process (2.98), receive adequate and timely information when the regulations change (2.44) and the traders are not demonstrating high levels of compliance about customs clearance (2.42). From the evaluation of efficiency is clear that the goods are cleared in time but customs clearance is not a transparent process. The issues related to port authorities through correlation could be found that there is a significance relationship between export and import issues and port authority issues.

Freight Forwarding Association activities should take effort and have been more active in solving the problems of forwarders in Chennai. The government of India should make some changes or reductions in the taxation for forwarders. Transparency in forwarding operations has to be improved. After the client accepts the proposal, the product should be checked physically by forwarder before it gets packed. Proper methods need to be implemented to get the payments on time. Forwarders should keep long term relationship with customers. Forwarders are the real source to enhance the export and import, so the customs should treat them well and in a prestigious manner. Proximity to CFS and ICD has to be facilitated.

\section{CONCLUSION}

Freight forwarders are thetravel agents for the freight. They are doing the best operations in India with the limited infrastructural facilities. The problems faced by forwarders is identified in a customs clearance perspective and it is very clear by the facts and figures that it is because of government regulations, the result of port authorities, insurance companies, customs clearance, infrastructural issues, payment issues etc. To overcome these problems the forwarders association have to be strongand they have to raise the voice mainly against the government so that the government will be forced to help the forwarder. The main problems India suffer in the shipping industry is because of infrastructure facilities. Technologies are improving now. Freight forwarders have to be very careful in accepting shipments from exporters and importers.

\section{REFERENCES}

[1] Appels Ton, Struye De Swielande \& Henry. (1998). International Journal of Logistics Management, 9(1), 111-11.

[2] Ankanth Kishore Saran. (2014). Dry ports in India - Need and Challenges, Governent of India Ministry of Shipping.

[3] Arvis, Jean-François, Michel Bellier \& GaëlRaballand. (2006). Success factors for improving logistics in a middle-income country. Transport Notes Series 35. World Bank, Washington, D.C.

[4] David. (2013). Difference between NVO and NVOCC operaor, Shipping and freight resource, The definitive online resource for shipping and freight information.

[5] Nishimura, Etsuk, Imai, Akio, Janssens, Gerrit \& Papadimitriou, Stratos. (2009). Container storage and transshipment marine terminals. Transportation Research Part E, Logistics and Transportation Review. 45, 771-786.

[6] Paul R. Murphy \& James M. Daley. (2001). Profiling international freight forwarders: an update. International Journal of physical Distribution and Logistics Management, 31(3), 152.

[7] Kim K.H. (2005). Models and Methods for Operations in Port Container Terminals. In: Langevin A., Riopel D. (eds) Logistics Systems: Design and Optimization. Springer, Boston.

[8] Wei Yim Yap, Jasmine Siu Lee Lam \& Notteboom. (2006). Developments in container port competition in East Asia, Transport Reviews, 2, 167-188. 